\title{
地すべりに関する新共振法による研究 A Study on the Landslide by a New Resonance Method
}

\author{
盛合禧夫*) ・ 松村吉康 ${ }^{*)} \cdot$ 阿部真郎**) ・ 森屋 洋**) \\ MORIAI Tomio $\cdot$ MATUMURA Yoshiyasu $\cdot$ ABE Shinro $\cdot$ MORIYA Hiroshi
}

\begin{abstract}
We have developed a new resonance method which enables us to measure resonant frequency and consequently to obtain propagation velocity by imparting vibrations to samples. And by this new method we can also estimate the strength of the materials through the obtained propagation velocities.

Over the past twenty-two years we have conducted seveal researches, using this new method. In our research in 1988 into steel tower footings whose underground concrete foundations dangerously deteriorated in the course of many years, we diagnosed their conditions without conducting any digging or excavation. Since 1995 we have been engaged in the preservation and the restoration of Angkor Monuments and carried out diagnoses on the rocks and the concretes of the monuments by this method.

The present article is the report about the excellent results we have gained by applying our new method to the studies of the soil samples from landslides in the Tohoku district. By studying the relationship between propagation velocity and water content, we have found that the strength of the soil declines with its changing process from elastic body to plastic body. Our findings are applicable to landslide prediction and protection measures.

Key words : plasticity, elasticity, slip surface, soil sample
\end{abstract}

\section{1.はじめに}

最近，新幹線や道路のトンネル，または高架橋のコン クリート・ジョイント等の不良個所からコンクリート塊 の落下が問題となっている。筆者らのうち盛合・松村は 平成元年から鉄塔基盤の形状 - 劣化の研究から始まり石 造遺跡およびコンクリートの診断・解析を行い，1999年 からはこれまで, 非常に困難とされていた地盤沈下地帯 の土質地盤にまで及んでいる。これらの計測・診断には 新共振法を用いて成果をあげている。

一般に土の内部組織の劣化や破壊の進行を知る目安は, 固体から塑性領域に入ったことである。すなわち，塑性 体になると弾性体としての性質も失うので, 非常に重要 である。そこで，共振法による測定で塑性体との関係が 把握できれば，災害発生の可能性を推定できるものであ る。塑性体になるには, 水・振動・風化およびその他の 要因がある。今回, 土質地盤が注水によって共振現象の 変化や共振現象が発生しないこと，すなわち固体から塑 性領域に入る点を総合的に解析した。

一般に, 従来の地盤工学での実験は長時間かかる複雑 なものが多いのに反し，筆者らの測定は簡単で短時間に 処理できる利点を持っている。

今回，筆者らは地すべり面粘土の測定を行い，今後地 すべりの予知および対策に応用したいと考えている。

\section{2. 共振法の原理}

有限の大きさを持つ弾性波は，それぞれの弾性波が複

*)東北工業大学

**)奥山ボーリング
雑に組み合わさって，伸縮運動やたわみ振動，ねじれ振 動等を起こし, その弾性体の材質・大きさ・形状によっ て決まる固有の振動数で共振する。この振動数を固有振 動数，または共振振動数と呼んでいる。このことから， ある弾性体に対して, いくつかの固有振動数と伝播速度 から，その弾性体の大きさ，形状を決定することができ る。さらに, この理論を展開・応用すると大きさ, 形状 が分かっている物では強度や劣化程度も推測できる。

この共振法は, モード解析が困難なため特定の形状の 物にしか用いられない。たとえばJISS1127の試験要項で は棒状の物と定められている。従って, 試料の形状に制 約があるため, 構造物の各部材を有るがままの状態で測 定することは，これまで行われていなかった。また，上 述の共振振動数を測定する装置は, 振動数を掃引して加 振機により試料の加振を行うが, 加振にはある程度パ ワーが必要なために装置が大きくなり持ち運びに不便で ある。

最近，デジタル技術の進歩によりFFT（Fast Fourier Transform）分析器が開発され，これとインパクト・ハ ンマーとの組み合わせにより, 種々の形状の物体におい ても共振振動数の測定が簡単に行えるようになった。こ れはインパクト・ハンマーで試料物体に軽く衝撃を与え， その物体に接触されたピックアップからの出力をFFT 分析器で分析し, 振動数応答を求める物である。この FFT分析器一インパクト・ハンマーの組み合わせの測 定器は, 測定が簡単で精度も良く, 携帯に便利な小型 $(3.2$ $\mathrm{Kg})$ の物も開発されている。従って, 野外の測定にも 適している。一般には共振振動数はf $\mathrm{f} v / 2 l$ で表される。 
ここで $v$ は振動の伝播速度であり, lがわかり $f$ 測定す るとvが求められる

$$
\begin{aligned}
& V=\sqrt{\frac{E}{\rho}} \quad E: \text { ヤング率 } \rho: \text { 密度 } \\
& f(n)=n \frac{V}{2 l} \quad n: \text { 正整数 }
\end{aligned}
$$

$V$ には 2 つり 1 つは上記のもので他のものはよこ波 の伝播速度で弾性体の場合は

$$
\begin{aligned}
& V s=\sqrt{\frac{E}{2(1+\nu \rho)}} \\
& f s=n \frac{V s}{2} \quad \text { レ: ポアソン比 }
\end{aligned}
$$

物体強度は（破壊強度も含めて） ヤング率 $E$ に密接に 関係があり，Eの大きいものは強度も大きい。なお現場 でFFTアナライザーによって測定した結果は即座に横 軸に振動数，縦軸に振動強度が表示され，これから共振 振動数を読みとっている。同じ材料でも劣化が進むと共 振が起こらなくなりグラフにはピークが存在しない。ま た，亀裂のある物体ではあるべき所に共振振動数が存在 しなかったり，共振が複雑になる。さらに，肉眼で見え ない亀裂が存在する場合も共振振動数は測定できないが, 内部破壊の進行を推定できる。従来までの研究では岩石 物性間の相関性は図ー1のように, 伝播速度と一軸圧縮 強度とは常に比例関係にあることが知られている。

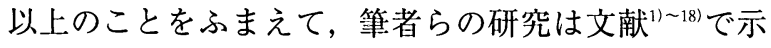
したように岩石およびコンクリートでの種々の測定, 解 析を重ね成果をあげてきた。そこで，今回原理的には全 く同じなのでこの測定を土に適用したものである。

\section{3. 土の測定方法}

測定対象の土壤を柔軟な筒状部材に充填し, 該筒状部 材の両端に硬質の板状体を設けて両端から加圧して，土 の粒子どうしが可能な限り接着させ, 地下数 $\mathrm{m}$ 程度の圧 力下の自然の地山と同じ状態にする。その一端の板状体

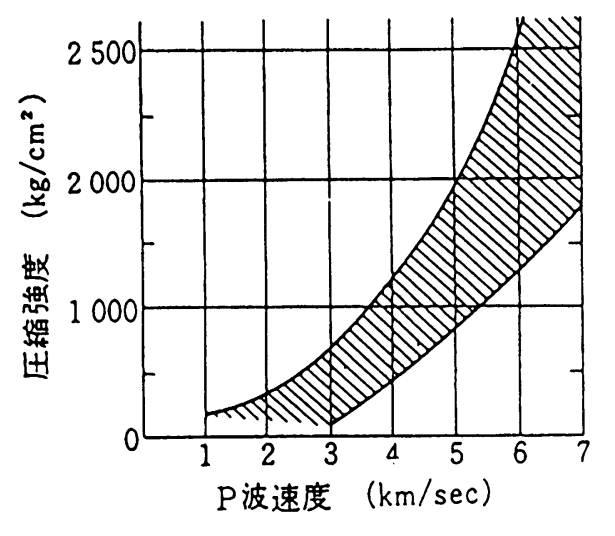

土木学会

土木技術者のための岩盤力学（1975）

図-1 弾性波速度と圧縮強度
を加振して充填された土壤の共振振動を測定し，共振振 動数を分析して土壤強度の度合を判定する土壌の測定法 である。また，測定対象の土壤の地表面あるいは地中に 間隔をおいて一対の金属板を配置し，一方の金属板には 振動手段を設け，他方の金属板には振動検知手段を設け て，土袞を加振して共振振動数を測定する。

ここで, 土壤も加圧して弾性体としたから，図－2の ような試料（この図は円柱状）の土壤, 即ち, 長さが $L$ で断面積はどのような形状でも良いが断面の最大寸法 $D$ が， $L>2 D$ である棒状の土壤を考えると，最も単純な 共振は長さ方向に平行な縦波的な伸縮振動の共振であり， この場合の基本波の共振振動数 $f$ は,

$$
f=\frac{V}{2 L} \quad V=\sqrt{\frac{E}{\rho}}
$$

で表され，共振振動数 $f$ を測定すると伝播速度 $V$ が求め

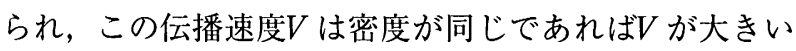
ほど強い材料であることが分かる。

\section{3. 実験結果}

\section{1 実施例 A}

上記の知見に基づき，図-3に示すような計測システ ムを組み立て使用したが，この実験例では測定対象の土 壤を柔軟な筒状部材に充填し，この筒状部材の両端に硬 質の板状体を設けて両端から加圧して, 板状体を加振し て，充填された土壤の共振振動数を測定し，該共振振動 数を分析して土䁃強度の度合を判定するものである。

なお, 土壤（岩石）10の振動を検出するための振動検 出手段として, 金属板13には振動検知センター15が取り 付けられているが，この取り付け手段は金属板13にネジ 止めしてあるが，瞬間接着剂等でもよく，金属板13に強 固に取り付ける必要がある。なお,この振動検知センター 15に替えて所定距離, 例えば $10 \mathrm{~cm}$ を隔てて指向性の強 いマイクロホンを設けてもよく，この場合には移動が容 易である。

\section{测定結果}

試料はカンボジア・アンコール遺跡における土壤と， 仙台七北田川の砂であって，以下の挙げるものである。

(1) 硬質な砂岩（クデイ（地名）の砂岩）をハンマーで 砕き，土粒子の大きさに調整した砂微粒子

(2) 沈下地帯の土（K-19の石柱の地盤で沈下している ところの土)

(3) 褐色土（前柱殿（クデイ）の北側の良好な土壌）

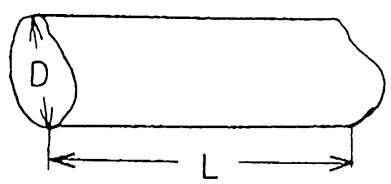

図-2 測定試験 


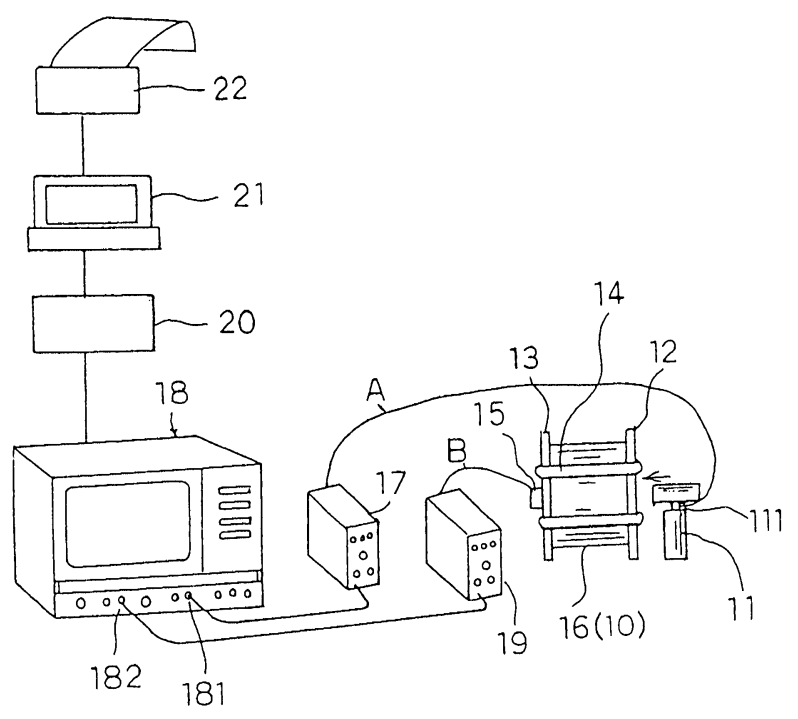

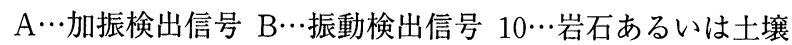
11 ㅅハクトハンマー $111 \cdots$ 力検出ピックアップ $12,13 \cdots$ 金属板 $14 \cdots$ ゴムバンド $15 \cdots$ 力検出ピックアップ $16 \cdots$ 布性筒状袋 $17 \cdots$ 前置増幅器 $18 \cdots$ FFT分析器 $181 \cdots$ FFTアナライザ部の第 1 チャンネル $182 \cdots$ FFTアナライザ部の同第 2 チャンネル

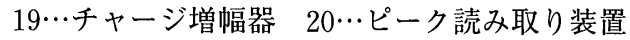
$21 \cdots$ ํソコン $22 \cdots$ プリンタ

\section{図一３測定装置システム}

(4) ラテライト性赤色土（バンテアイ・クディの参道）

(5) ラテライトを 1 と同様に粉砕した微粒子

(6) 仙台七北川の砂

これらの試料を, 長さ約 $10 \mathrm{~cm}$ で直径が $5 \mathrm{~cm}$ の筒状の 布袋に入れ，両側に金属板 $12 \cdot 13$ を密着させ， 7 本のゴ ムバンド14で両側から圧縮し金属板13には振動を検知す るセンサー15を固着した後, 共振周波数を検出し伝播速 度を算出する。

(1)〜 (6)までの乾燥状態での各土壤の共振法で伝播速度 の数值を求めるが, 例えば, (5)ラテライトをハンマー で砕き粉砕した微粒子の乾いた状態での周期数応答関数 （1番目の波の形）での共振周波数は $1.22 \mathrm{KHz}$ で，補正

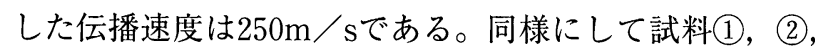
(3), (4), (6)の各土の共振法で伝播速度の数值を求め, 従 来の一軸圧縮試験の測定值と比較したのが図一 4 で, ほ ぼ同じ傾向にあることが判る。次に, これらの試料は最 初は乾かした状態から, 次第に注水して, その都度, 共 振周波数を検出し伝播速度を算出した。例えば，試料6 に水を $7 \mathrm{~g}$ 注入した共振周波数は $1.24 \mathrm{KHz}$ で，水を $20 \mathrm{~g}$ 注入した共振周波数は $1.09 \mathrm{KHz}$ で伝播速度は徐々に下 がっていき, 強度も下がっていく。同様に, 試料(1)〜6) までの各土壌の試料を測定した結果が, 図ー 4 , 表 -1 である。水が浸透した場合の変化をみると, 最も弱いも のは砂岩より構成された砂質土で, 最も弱いものはラテ ライトの粒子やラテライト性赤色土である。この点は, 従来の方法では適格に測定することが全く困難なもので
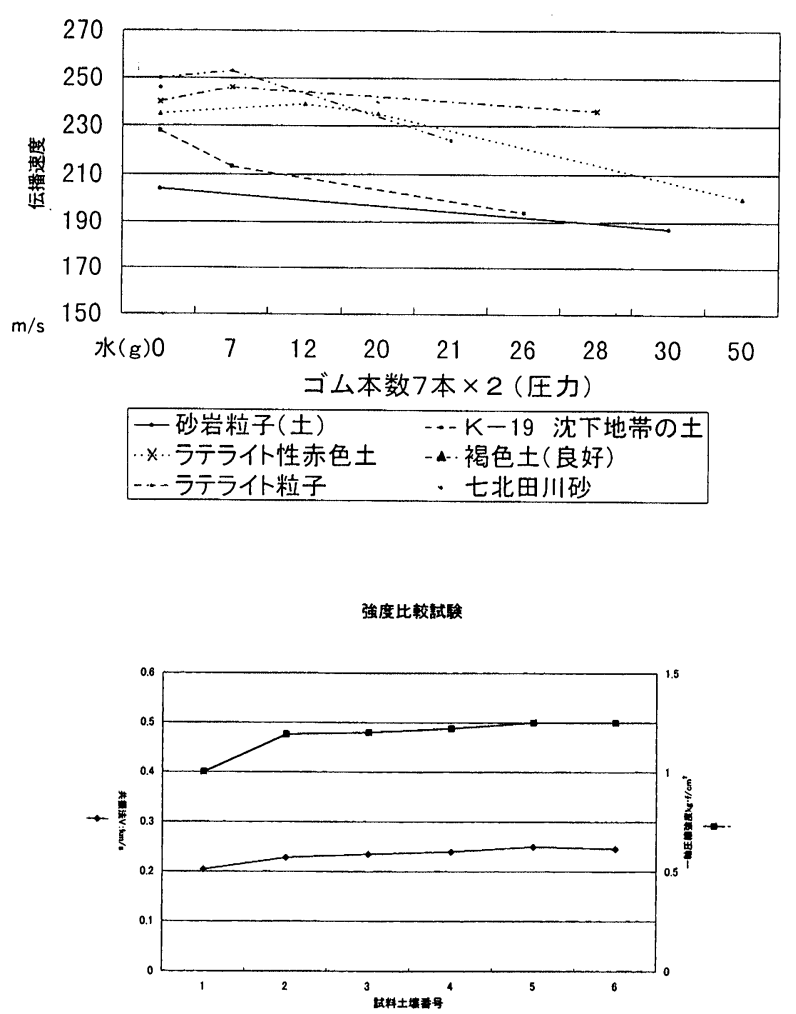

図－4 各種土の伝播速度・水分および圧縮強度との関係

あった。

また, 沈下地帯の試料の土の強度值が最も小さく砂岩 の粒子の数値と非常に似ており，これは，この地盤の構 成では砂岩を源岩でることを反映していることから，極 めて興味ある事実が判明した。これらの土壤の強度の強 弱の程度を比較すると試料(4)>(3)>(2)となり, 理論上で 考えられる傾向とも一致する。

ただし，水の付加で一時的に強度が上がり土粒子間の 接着の効果を上げることがあるが，K-19試料(2)と砂岩 粒子(1)はその効果が現れない。最終的には水分の増加は 劣化の促進という効果を与えることだけは共通している。 実験方法にも，ゴムバンドで土粒子を密着させて共振現 象を見る際に，このゴムバンドの圧力を定量的に調査し て共振現象との比較が必要であったが，圧力は概略の目 安と考えて, 本実施例で各試料に対する圧力をほぼ同じ 程度にした。すなわち，ゴムバンドの圧力は地上・又は 地中の圧力に相当するところの伝播速度である。そこで， 圧力が変われば速度も変わる。試料(1)〜 (6)はその圧力下 での值として有効であり, 強度判定の重要な目安となる。 また，ラテライトの粒子は加水すると急激に伝播速度が 下がるが，ラテライト中のカオリン・微粒状赤鉄鉱等が 粘性土と同じく急激に溶脱するのがその原因と思われ， 本実施例の測定した検証結果において, 土壤の強度の度 合が測定できるという事実を否定するものではない。

次に, 試料の両端での圧力と伝播速度との関係をバコ ン（アンコール遺跡）のラテライト性赤色土について検 証した。 
表一 1 図- 4 の測定値

\begin{tabular}{|c|c|c|c|c|c|}
\hline \multirow{2}{*}{ 要号 } & \multirow{2}{*}{ 名称 } & \multirow{2}{*}{$\begin{array}{r}\text { 条件 压力 } \\
\text { 長さ } \\
\text { 注永 } \\
\text { 葡料 } \\
\text { の長さ }\end{array}$} & \multirow{2}{*}{$\begin{array}{l}\text { Freq- } \\
\mathrm{KHz}\end{array}$} & \multicolumn{2}{|c|}{ 捕正壾真值 } \\
\hline & & & & $v: k m / s$ & 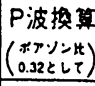 \\
\hline 1 & 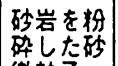 & $\begin{array}{r}5 \angle 7 \text { 本 } \times 2 \\
\ell: 8.6 \mathrm{~cm}\end{array}$ & & & 0.242 \\
\hline & 微䎦子 & 注水铇和 & 0.97 & 0.188 & \\
\hline 2 & $\begin{array}{l}\text { 沈下地带 } \\
\text { の土 } \\
\text { K19の土 }\end{array}$ & $\begin{array}{c}\text { コム } 7 \text { 本 } \times 2 \\
0: 8.6 \mathrm{~cm} \\
\text { 水 } 0 \\
\text { 水 } 79 \\
\text { 水 } 26 \mathrm{~g}\end{array}$ & $\begin{array}{l}1.14 \\
1.07 \\
0.96\end{array}$ & $\begin{array}{l}0.228 \\
0.214 \\
0.194\end{array}$ & 0.273 \\
\hline 3 & $\begin{array}{l}\text { 襣色士 } \\
\text { 甚好な士 } \\
\text { KB2 }\end{array}$ & $\begin{array}{c}コ ム 7 \text { 本 } \times 2 \\
0: 8.6 \mathrm{~cm} \\
\text { 水 } 0 \\
\text { 水 } 12 \mathrm{~g} \\
\text { 水 } 20 \mathrm{~g} \\
\text { 水约和 } \\
(50 \mathrm{~g})\end{array}$ & $\begin{array}{l}1.18 \\
1.21 \\
1.19 \\
1.01\end{array}$ & $\begin{array}{l}0.235 \\
0.239 \\
0.235 \\
0.200\end{array}$ & 0.281 \\
\hline 4 & $\begin{array}{l}\text { ラテラィ } \\
\text { 性 } \\
\text { 赩土 }\end{array}$ & $\begin{array}{l}コ ム 7 \text { 本 } \times 2 \\
Q: 8.8 \mathrm{~cm} \\
\text { 水 } 0 \\
Q: 8.8 \mathrm{~cm} \\
\text { 水 } 7 \mathrm{~g} \\
Q^{2} 8.7 \mathrm{~cm} \\
\text { 水 } 28 \mathrm{~g}\end{array}$ & $\begin{array}{l}1.18 \\
1.22 \\
1.19\end{array}$ & $\begin{array}{l}0.240 \\
0.246 \\
0.236\end{array}$ & 0.287 \\
\hline 5 & 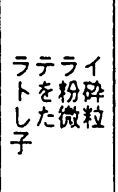 & 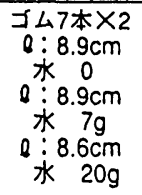 & $\begin{array}{l}1.22 \\
1.24 \\
1.09\end{array}$ & $\begin{array}{l}0.250 \\
0.253 \\
0.224\end{array}$ & 0.299 \\
\hline 6 & $\begin{array}{l}\text { パコン } \\
\text { ラ三うへ } \\
\text { 性赤色 } \\
\pm\end{array}$ & $\begin{array}{c}0: 9.1 \mathrm{~cm} \\
\text { 水 } 0 \\
\checkmark 47 \text { 本 } 22 \\
10 \text { 本 } 22 \\
14 \text { 本 } \times 2 \\
18 \text { 本 } \times 2\end{array}$ & $\begin{array}{l}1.35 \\
1.50 \\
1.61 \\
1.72\end{array}$ & $\begin{array}{l}0.280 \\
0.307 \\
0.327 \\
0.347\end{array}$ & 0.335 \\
\hline 7 & $\begin{array}{l}\text { 仙台 } \\
\text { 七丠田川 } \\
\text { の数 }\end{array}$ & & & 0.246 & \\
\hline
\end{tabular}

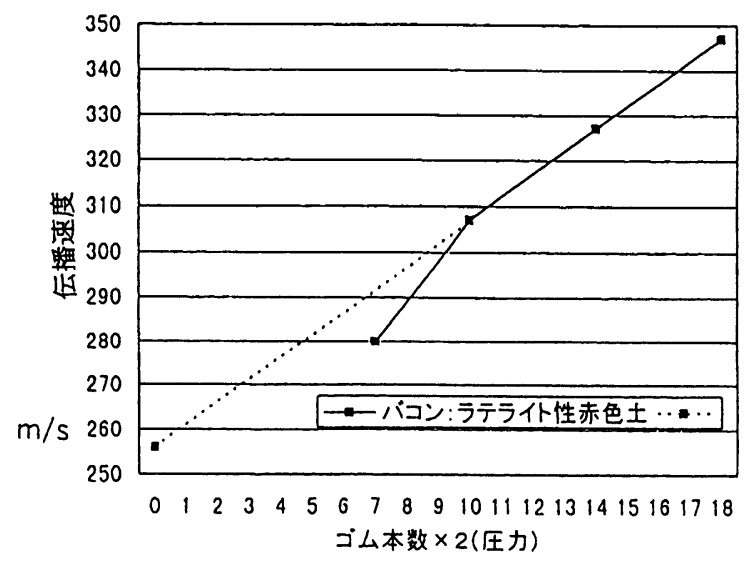

図ー 5 ラテライト性赤色土(パコン地区)の伝播速度と圧力
その結果は図－ 5 におけるゴムバンドの本数を変える ことにより圧力を変えて测定した結果を表－1に示すが， 圧力 7 本 $\times 2$ (ゴムバンドの本数) では $280 \mathrm{~m} / \mathrm{s}$ 示し, 圧力を 10 本 $\times 2,18$ 本 $\times 2$ と順次に増加させて測定して いくと共振周波数は上昇し, 伝播速度は $307 \mathrm{~m} / \mathrm{s}, 327$ $\mathrm{m} / \mathrm{s}, 347 \mathrm{~m} / \mathrm{s}$ 直線上に比例関係を保ちながら上昇 する。これは, 圧力をかけると土粒子間がよく密着し, 弾性体として物性を示す理論と一致することが分かる。 この測定も従来の試験方法では困難なものであった。

なお, 圧力が 0 の点での伝播速度の值はこの直線上の 延長上にあるので $256 \mathrm{~m} / \mathrm{s}$ 図表により確認でき, この 值はフックの弾性体の限界を意味しており, これ以下で は弾性体の性質を示さないことになる。

これは固体, 半固体, 塑性, 液性と区分なかでは塑性 領域のような状態, いわば未固結の土粒子間が非常に伝 播しにくい状態を意味しているものと解釈できる。

以上検証したように, 実施例Aは共振周波数からの伝 播速度を検出することで, 比較的簡単に土畩の強度を推 定することができ, その結果，土壤の種類を判別でき， また, 水の浸水状態の変化にともなう土壤強度の変化や, 土壤での加圧の変化にともなう土壤強度の変化を知るこ とができた。

\section{2 実施例 $B$}

この実施例はAの実施例と測定原理はほぼ同じであり，

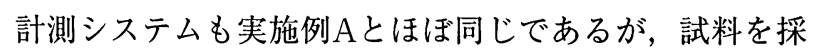
取することなく測定ができる。土壌の地表面あるいは地 中に間隔をおいて一対の硬質の板状体を配置し，一方の 板状体を加振して土壤の共振振動数を測定し, 共振振動 数を検出して土壤の強度の度合を判定するものである。

実施例Bは図 - 6 に示すように, 測定対象の土猿の層 に平行に $20 \mathrm{~cm} \times 20 \mathrm{~cm}$ の正方形の金属板一対 31,32 を, $20 \mathrm{~cm}$ の間隔で面を平行にして配置する。一方の金属板 31 外側面には，インパクト・ハンマー11で打撃するス ペースを設け，他方の金属板 32 の外側面には振動を検査 するセンサー15を固着する。

この実施例は, なによりも簡便に強度測定ができ, 水 の浸水状態や圧力状態の変化にともなう土袞の強度の変

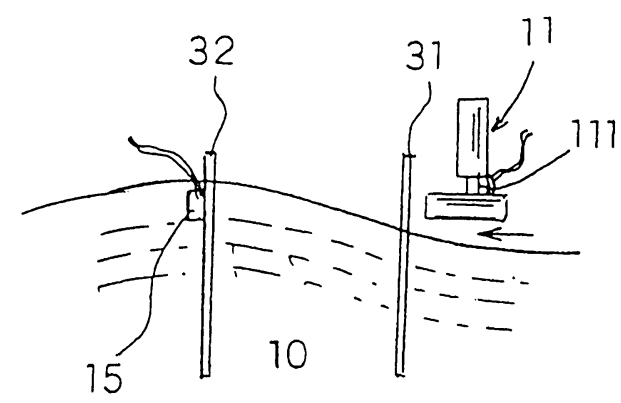

$10 \cdots 土 \quad 11 \cdots$ インパクトハンマー $15 \cdots$ 力検出ピックアップ $31,32 \cdots$ 金属板 $111 \cdots$ 力検出ピックアップ

図ー6 野外における岩石または土の測定法 
化をリアルタイムで検出することができる。また，装置 としては振動検出センサーは測定対象物に固着しなくて も, 所定距離を隔てて指向性の狭いマイクロホンでもよ く，この場合に装置の移動が簡単である。更に，基準と なる土壤の強度や特徴を測定装置の記憶手段に記憶して おけば，常にこの土壤強度の数值と比較して即座にその 土壤の強度や分類が可能になる。

\section{3 実験例C一地すべり面の粘土一}

試料採取地は下記のとおりである。

谷地はグリーンタフ中の泥岩を中心とした大規模岩盤 地すべりであり，仏社は同様の凝灰質粘土を中心とした ものである。芦萢はグリーンタフの大童子層の泥岩と崩 積土を含む地すべりで，下前はグリーンタフ中の地すべ りで, $\mathrm{R}(338)$ は強風化千枚岩と崩積土が地すべりである。

表一２＼cjkstart地すべり面粘土の採取地

\begin{tabular}{|l|l|}
\hline \multicolumn{1}{|c|}{ サンプル名 } & \multicolumn{1}{c|}{ 場 所 } \\
\hline 谷地 & 秋田県雄勝郡東成瀬村 \\
\hline 仏社(ブッシャ)(1), (2) & 秋田県北秋田郡上小阿仁厸社地内(サンプル 2 (1),(2)) \\
\hline 芦萢(アシヤチ) & 青森県西津軽郡深浦町大字長慶平字芦萢地内 \\
\hline 下前 & 青森県北津軽郡小泊村下前地内 \\
\hline R338(佐井) & 青森県下北郡佐井村大字穴潤沢地内 (長後) \\
\hline
\end{tabular}

既述の地すべり面粘土の注水と伝播速度がどのように なるかを図ー 7 に示した。どの粘土も水の付加（含水量 の増加）によって伝播速度は直線的に下降し，概ね 140 〜170ccで弾性体が塑性体に変わり共振現象は発生しな い。なお，この図では共振現象が 2 ヶ所認められる。こ れを 1,2 と表している。この理由はよこ波ではねじれ 振動の共振で低い振動数(1)のところに出て, 高いところ の振動数は棒状の伸縮振動なのでたて波的な共振になる (2)。更にベトべトになると，たて波的共振はなくなりね じれ振動だけになる。また以下の共振図は同一条件で 1 回のハンマーでの振動で出てくるスペクトルの横軸共振 振動数の位置のみが重要である。

次に測定結果を示す。

表- 2 に示す。

$L$ : 長さ (試料)

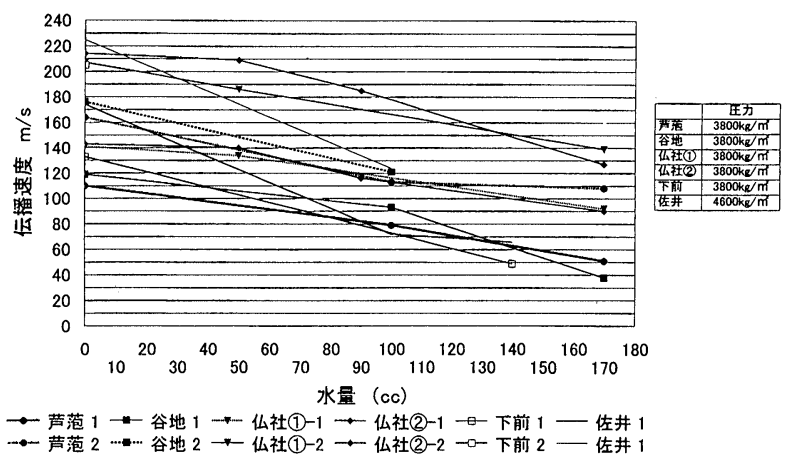

図ー7 地すべり粘土・伝播速度・水との関係
表ー 2 地すべり粘土・水分・および伝播速度との 関係の測定值

\begin{tabular}{|c|c|c|c|c|c|c|c|}
\hline 地区名 & & & $f(\mathrm{KHz})$ & $\frac{v(m / s)}{1}$ & $\frac{f(\mathrm{KHz})}{2}$ & $\frac{v(\mathrm{~m} / \mathrm{s})}{2}$ & L:cm $\quad m: z \quad p: k z / m^{\prime}$ \\
\hline 地区各 & & 水 & 1 & 1 & 2 & 2 & \\
\hline 谷地 & 乾煏前 & 直然状態 & 0.45 & 117 & 0.66 & 172 & $L=13.0 \mathrm{~m}=530 \mathrm{p}=3800 \mathrm{pH}=2.5$ \\
\hline & 乾燥後 & 0 & 0.50 & 119 & 0.74 & 176 & $L=11.9 \mathrm{p}=3800$ \\
\hline & & 100 & 0.39 & 93 & 0.51 & 121 & \\
\hline 仏社(1) & 颙及而 & $\frac{170}{170}$ & $\frac{0.16}{0.29}$ & $\frac{38}{78}$ & $\overline{0.43}$ & 116 & $L=13.5 m=530=4600 \mathrm{pH}=6$. \\
\hline & 颙啅後 & 0 & 0.54 & 141 & 0.79 & 207 & $L=13.1 \mathrm{p}=3800$ \\
\hline & & & & 134 & 0.71 & 186 & \\
\hline & & 170 & 0.35 & 92 & 0.53 & 139 & \\
\hline 仏社(2) & 颠祝前 & 直然状留 & 0.29 & 76 & 0.44 & 115 & $L=13.1 \mathrm{~m}=470 \mathrm{\rho}=4600 \mathrm{pH}=4.6$ \\
\hline & 乾燥後 & 0 & 0.57 & 143 & 0.81 & 214 & $L=11.9 p=3800$ \\
\hline & & 50 & 0.53 & 140 & 0.79 & 209 & \\
\hline & & 90 & 0.44 & 116 & 0.70 & 185 & \\
\hline & & 170 & 0.34 & 90 & 0.48 & 127 & \\
\hline 芦葋 & 乾揫前 & 自然状隹 & 0.26 & 74 & 0.48 & 137 & $L=14.3 \mathrm{~m}=560 \mathrm{p}=4600 \mathrm{oH}=5.5$ \\
\hline & 乾媟後 & 0 & 0.43 & 110 & 0.64 & 164 & $L=12.8 p=3800$ \\
\hline & & 100 & & 79 & 0.44 & 113 & \\
\hline 下前 & 酸如前 & $\frac{170}{1}$ & $\frac{0.20}{0.31}$ & $\frac{51}{86}$ & 0.42 & 108 & 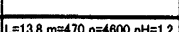 \\
\hline & 㲦婐後 & 0 & 0.51 & $\frac{\pi}{133}$ & 0.79 & 205 & $L=13.0 \mathrm{p}=3800$ \\
\hline & & 130 & 0.19 & 49 & & & \\
\hline 偖井 & 配絮前 & 直然状怔 & 0.36 & 96 & 0.54 & 144 & $L=13.3 \mathrm{~m}=470 \mathrm{p}=4600 \mathrm{pH}=5.8$ \\
\hline & 配然後 & 0 & 0.63 & $\overline{174}$ & 0.82 & 226 & $L=13.0 \mathrm{p}=4600$ \\
\hline & & 100 & 0.26 & 72 & 0.45 & 124 & \\
\hline
\end{tabular}

$m:$ 質量

$p:$ スプリングによる軸方向の圧力

$p H:$ 水素イオン濃度

この中で谷地を例として図 $8-1,-2,-3,-4$ に 示した。 2 ヶ所の共振現象は図中，1，20位置であり， カーソルで読みとったものである。縦軸は対数目盛での 振動数に比例した電位であり, 横軸は振動数でKHZで ある。これより計算で速度を求めている。

図 $9 \sim 13$ も全く同様なので図のみ示している。

また, 図一14ではpH, 液性限界, 塑性限界, 最低伝 播速度（地すべり，崩壊，沈下などが最も発生の可能性 がある值）および湿潤後の強度比（最初の乾燥時の伝播 速度と注入後の共振現象が発生しなくなった最後の速度 との強度換算比）との相関性を示している。全体的に総 べて大局的には相関性を持つが，塑性限度と湿潤後の強 度比は最も強い相関性を有している。特に共振が 1 と 2 では 1 の方が塑性限度と調和てきである。これは含水し 飽和するとねじれ振動を生じるためである。

\section{4. まとめ}

以上説明したように土壤の新共振法測定装置を使用し た。これにより, 土壤の内部組織の劣化の度合や品質分 類, 地盤沈下の度合, 地すべりの可能性, 土壤強度を総 括的に把握することが可能となり，また，土壤は含水量 の違いで固体 ·半固体 · 塑性・液性へと変化し, 加圧状 態の変化によっても土壌強度が変わるが, これらのどの 状態でも土壤を分解や破壊することなく土壤強度の推定 や判断が可能であり, 必要に応じてその変化の過程をり アルタイムで把握することも可能である。

なによりも測定装置が簡単であって装置の移動を容易 であり装置を設定することも簡単であることから，短時 間で土壤の強度測定ができるという効果が得られる。

また, 土袞が塑性体に変わる時点から地盤の破壊・地 すべり沈下が発生することが多く, 従って, 土壌の含水 比の増減により災害発生の予知にも大いに貢献できるも 
谷地（乾燥前）

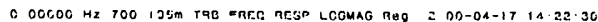

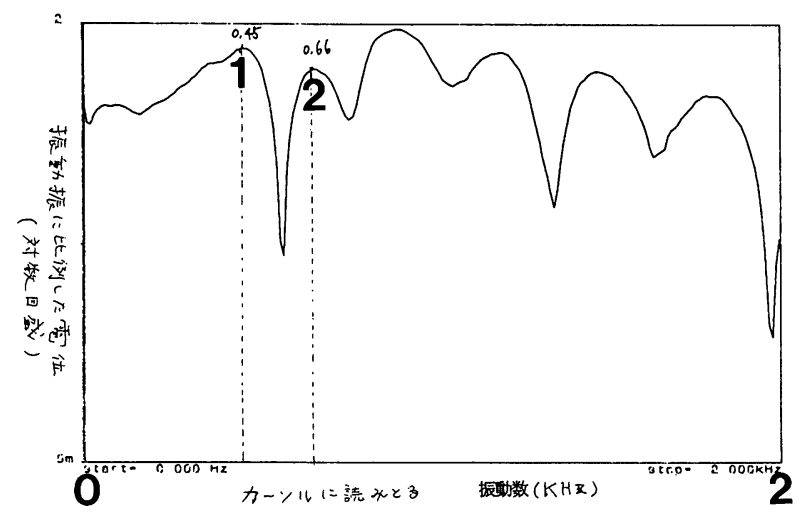

谷地 水 $100 \mathrm{cc}$

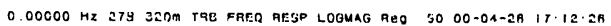

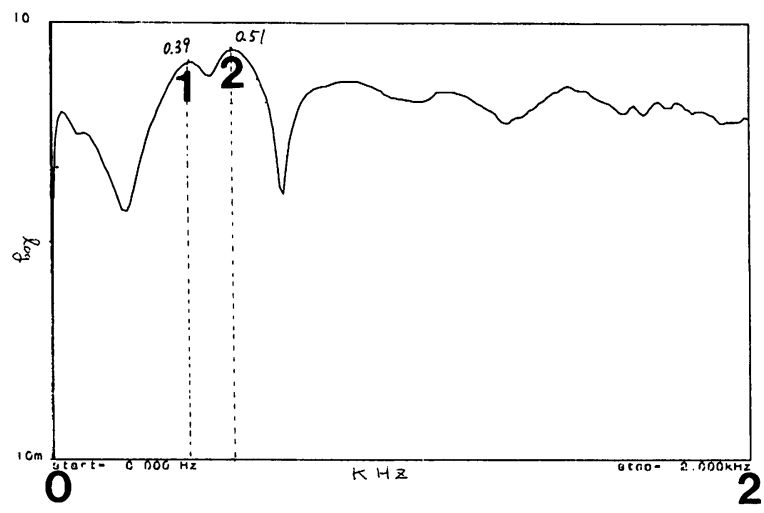

谷地 (乾燥後) 水 0

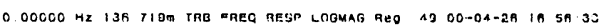

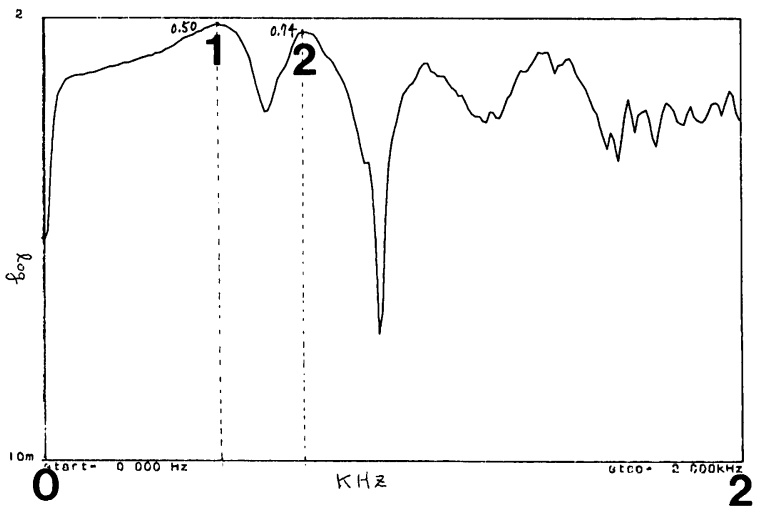

谷地 水150cc

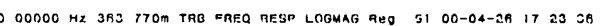

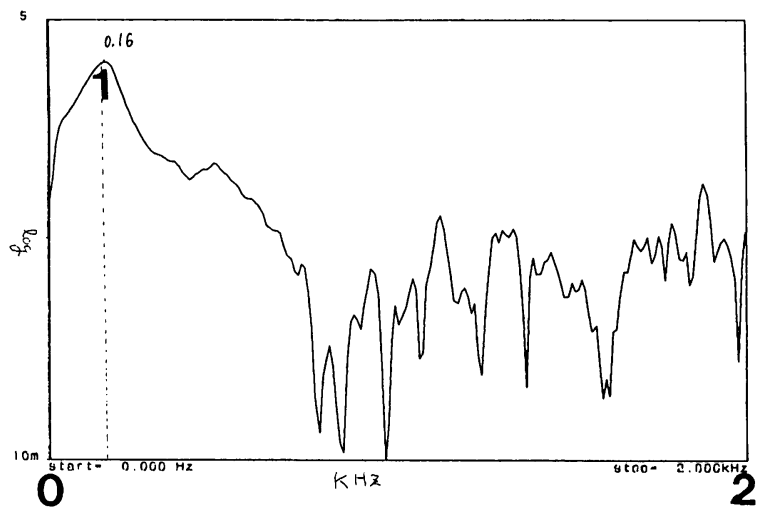

図－8 谷地地すべり粘土の水分注入時毎の共振振動周波数のスペクトル図

(4) IL (1) (ix $\times$, n)

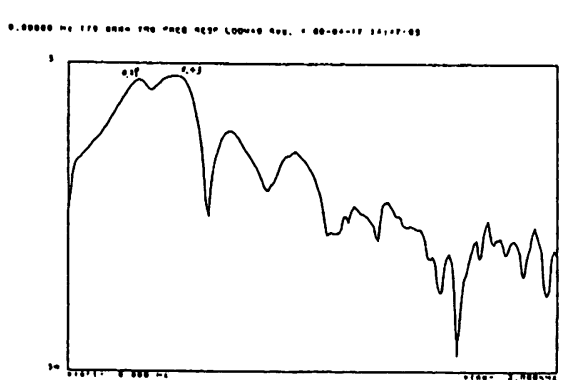

(4) $1(0)$

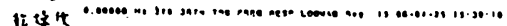

k.

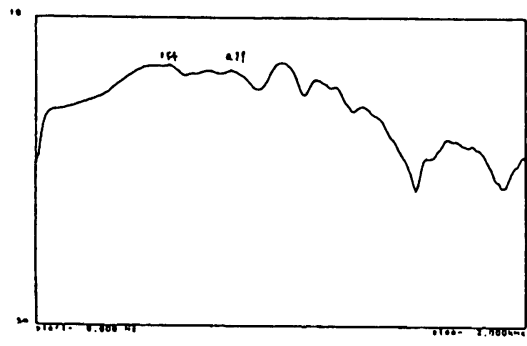

(4) (1)

i is ${ }_{\text {s }}$ soce

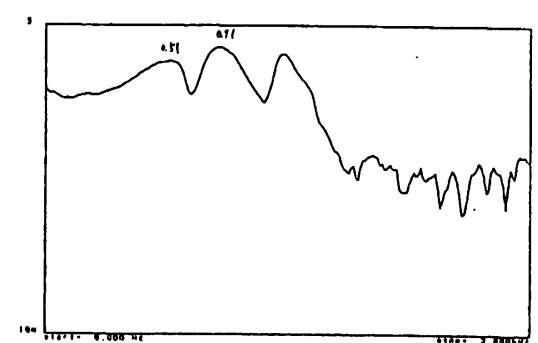

(4) (1)

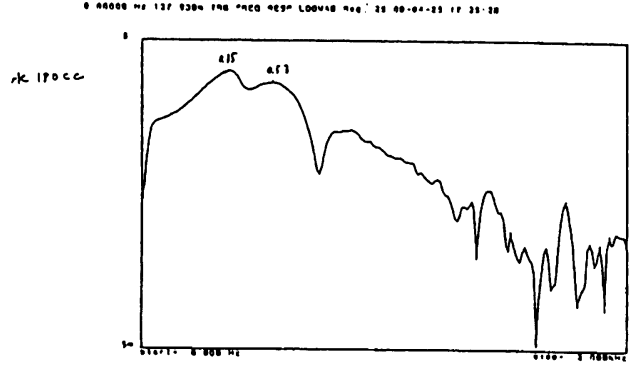

図ー9 仏社(1)地すべり 
4 is (2) (1: सम
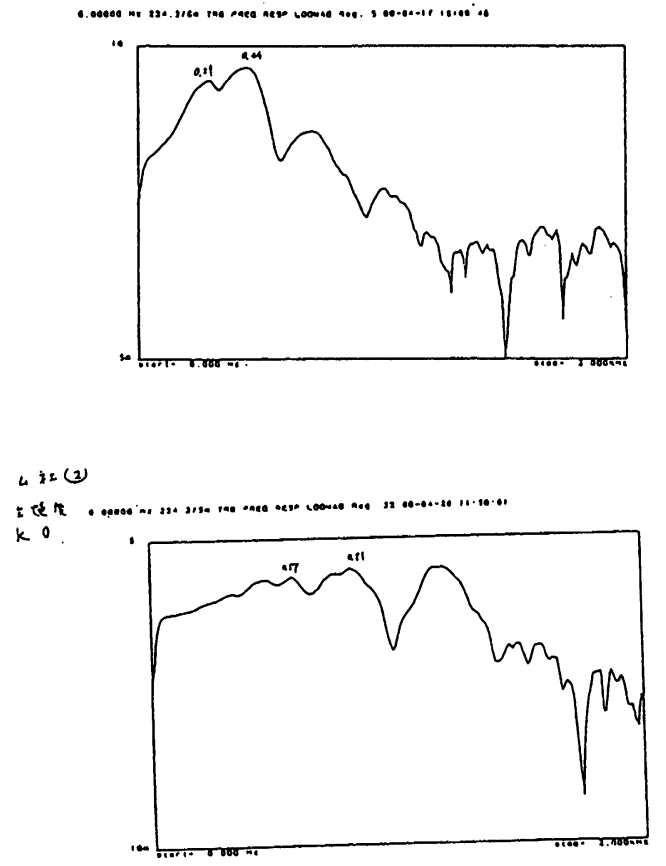

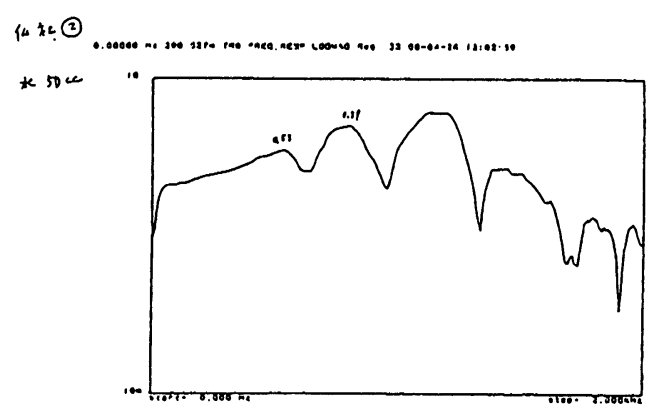

14 if (2)

aree

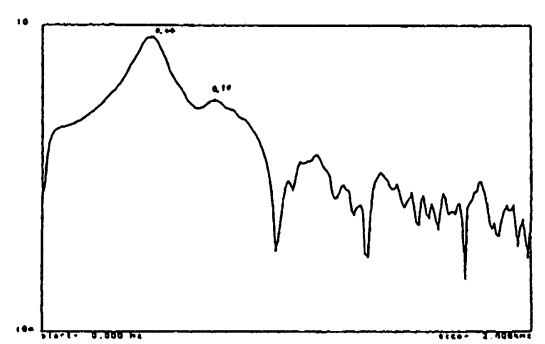

位 $1=$ (2)

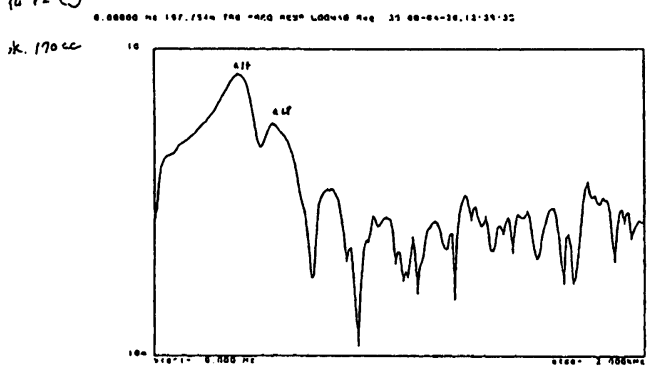

図ー10 仏社(2)地すべり

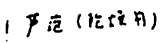

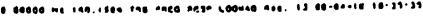

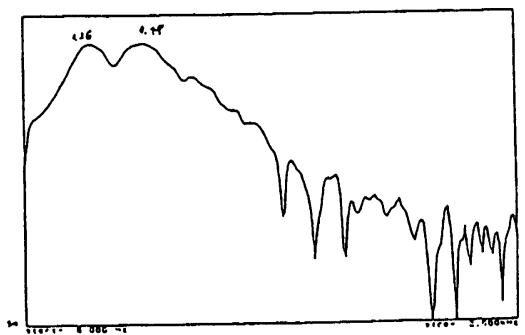

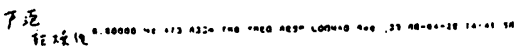

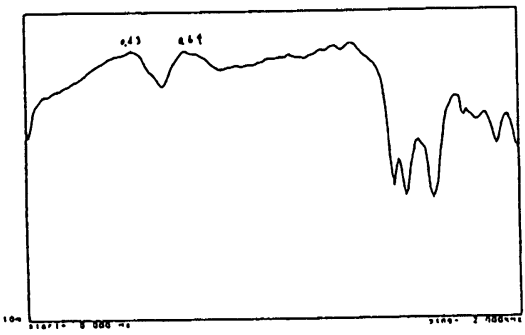

$7 \sqrt{\overline{2}}$

水 $100 \mathrm{ce}$

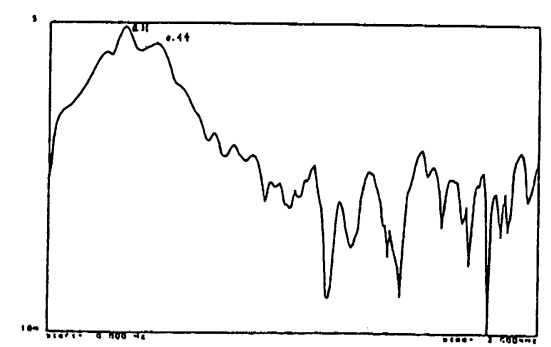

$7 \pi$

te $170 \mathrm{ce}$

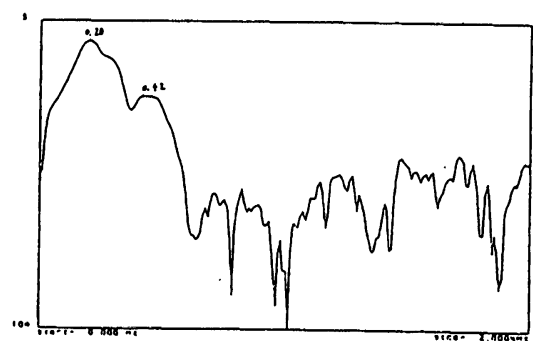

図ー11芦萢地すべり 

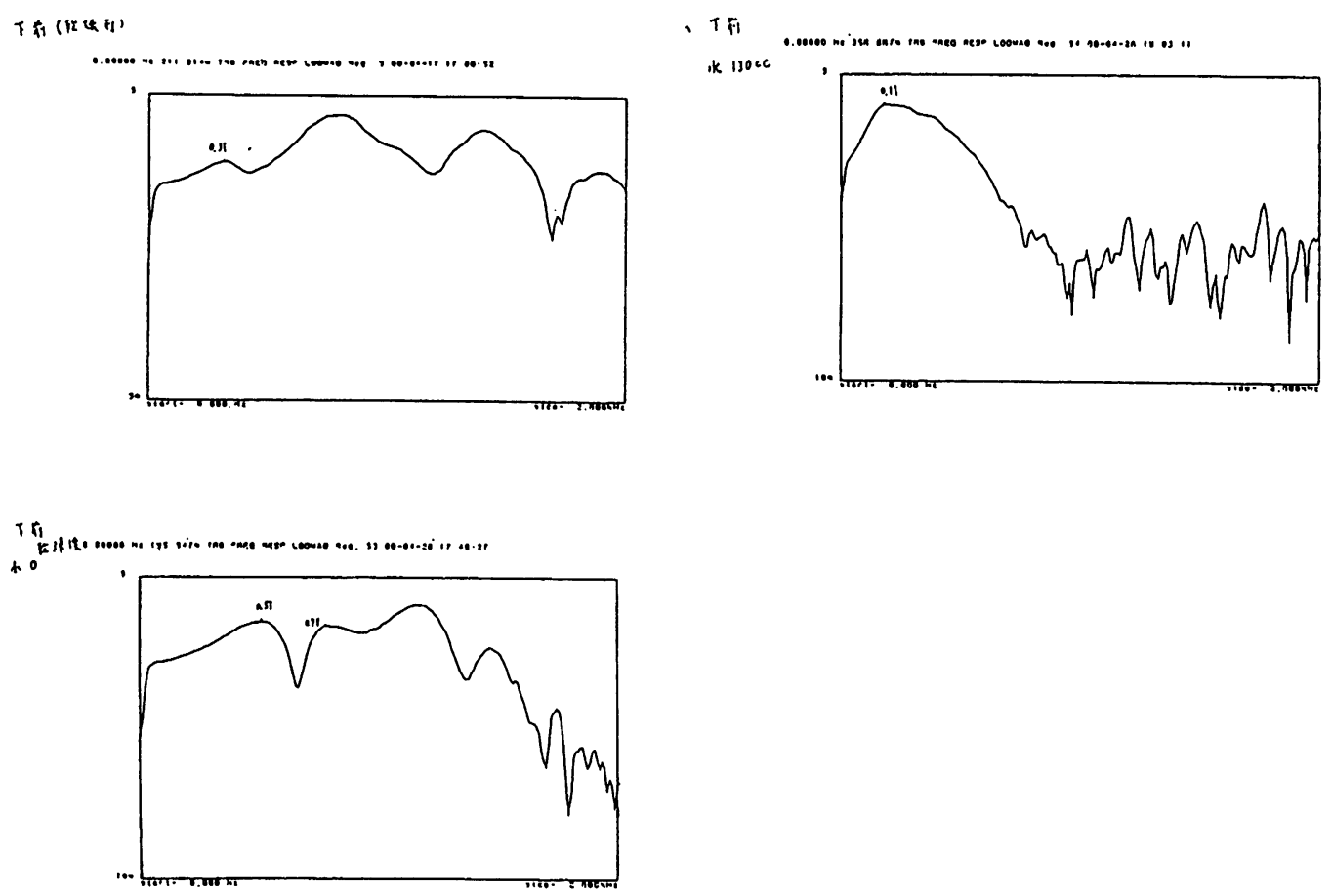

図-12 下前地すべり

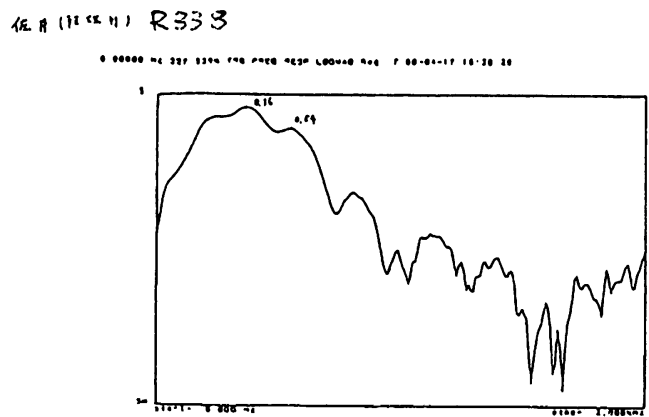

促 $* R 333$

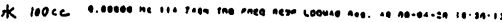
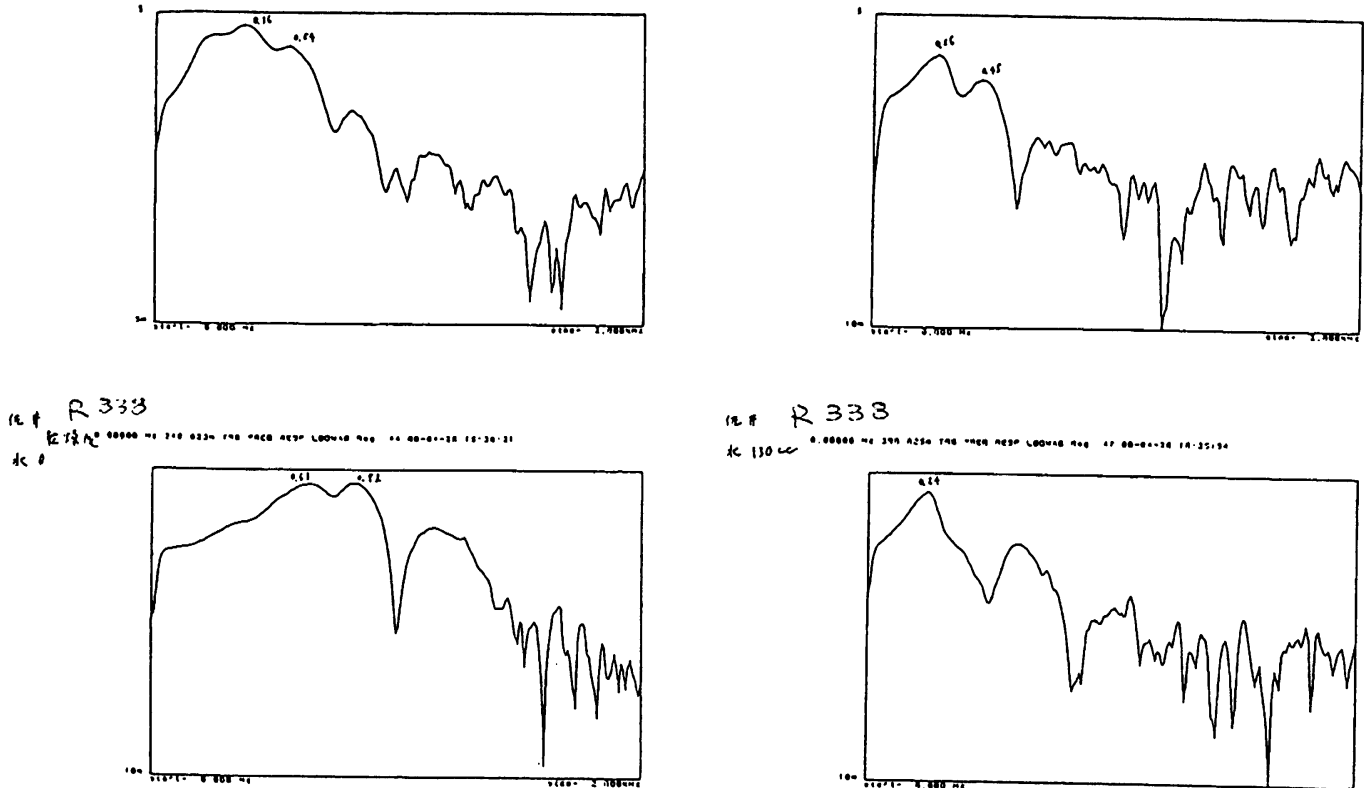

in $R 333$

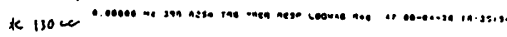

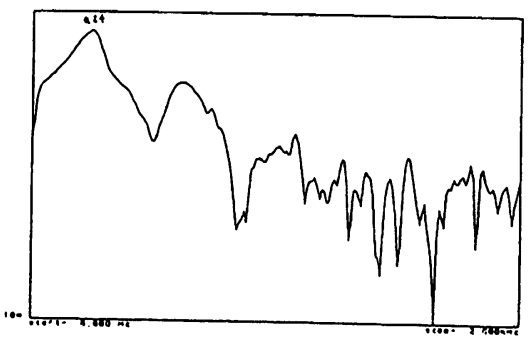

図一13 佐井地すべり 

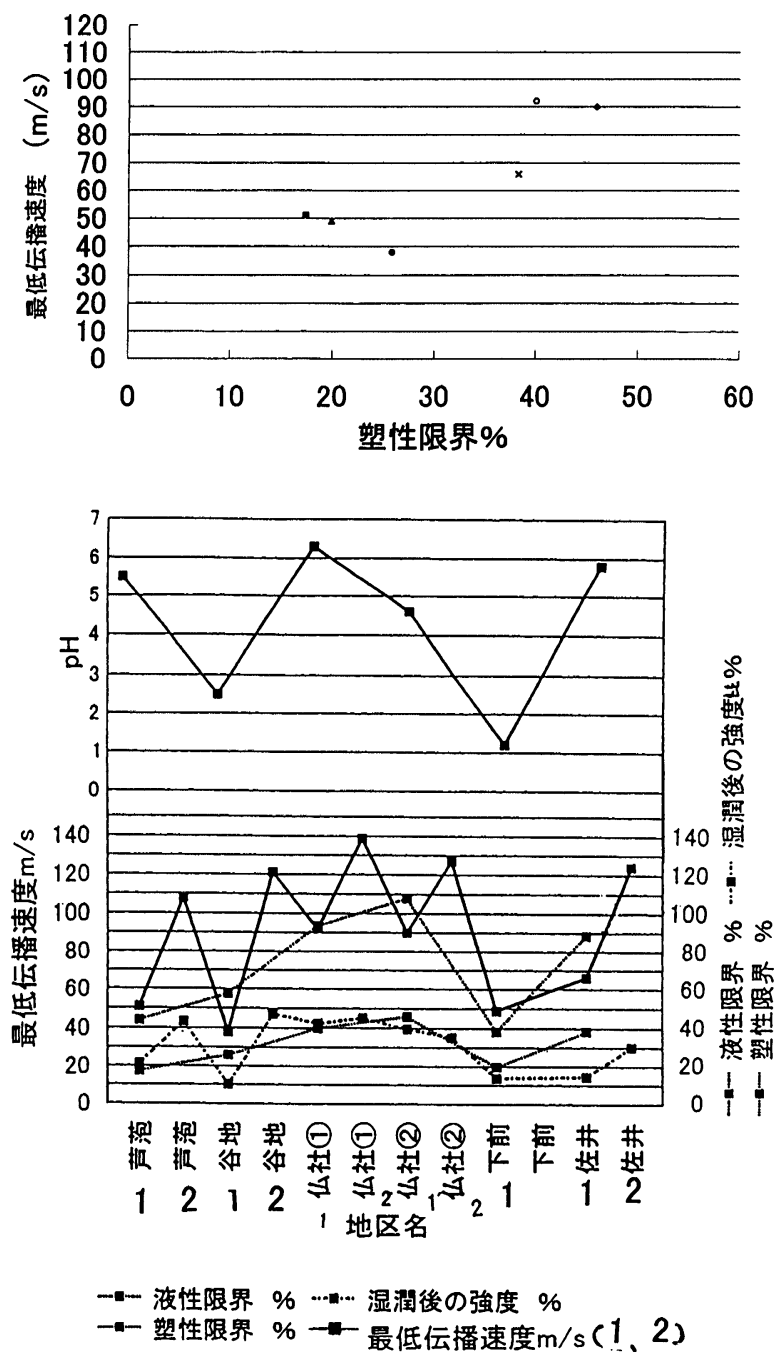

図-14 地すべり粘土の最低伝播速度, 液性限界·塑性限界, $\mathrm{PH}$, 湿潤後の強度との関係

のである。

これらのことから地すべり発生の可能性には，現地の 土の採取後あるいは現地での測定により簡単に決定でき ることが思料された。

\section{引用文献}

1) Evans, A. G.: Fracture Mechanics of Ceramics I, Plenum Press, N. Y.1976 (英文)

2 ）満永 豊・勝山 豊・小林敬和・石田之則：スクリーニング 試験による光ファイバ強度保証法, 電子通信学会誌, ' $87 / 7$ Vol.J66-B, No. 7, pp. 829-836

3 ) Y. Matumura A. Ishikawa Y. Akama $\cdot$ N. Chiba $\cdot$ T. Mo- riai : Study on Relations between Shapes and Resonant Frequencies of Elastic Body by Electrical Circuit Theory. 東北 工業大学紀要 I, 理学編, 15号, (1995), pp. 19-28 (英文)

4 ）盛合禧夫・奈良国立文化財研究所・大阪土質：1995年Banteay Kdeiのボーリング調査による地盤工学的研究, カンボジアの 文化復興（上智大学アジア文化研究所）No.12 (1995) , pp. 23 $-30$

5 ）盛合禧夫・松村吉康・赤間芳雄 : 新手法による石材の診断力 ンボジアの文化復興（上智大学アジア文化研究所）No.12 (1996), pp. $31-32$

$6 ）$ 盛合禧夫・松村吉康・赤間芳雄・ラオ キム リアン：カン ボジア・アンコール遺跡における主要構築素材に関する基礎 的研究 $-1-$, 東北工業大学紀要 I, 理工学編, 16号, (1996), pp. $47-60$

7 ）盛合禧夫・松村吉康・赤間芳雄：フランス極東学院による癩 王のテラス，象のテラスの修復用の砂岩・ラテライトの性状, カンボジアの文化復興（上智大学アジア文化研究所）No.13 (1996), pp. 47-53

8 ）盛合禧夫・松村吉康・赤間芳雄：バンテアイ・クディにおけ る共振法による石材の診断, 一第 2 報一，カンボジアの文化 復興 (上智大学アジア文化研究所) No.13 (1996), pp. 54-55

9 ）盛合禧夫・松村吉康・赤間芳雄：バンテアイ・クデイにおけ る共振法による石材の診断, 一第 3 報一

10）盛合禧夫・松村吉康・クム ソリッド：バンテアイ・クデイ における共振法による石材の診断, カンボジアの文化復興 (上 智大学アジア文化研究所） No.14（1997), pp. 13-16

11) T. Moriai $\cdot Y$. Matsumura $\cdot$ Koum Sorith: Diagnosis of the stone of Anghor Vat and Bayon Region, Renaissance Culturelle du Cambodia (Institute of Asian Cultures, Sophia University） No.14（1997）, pp. 231-232（英文）

12) T. Moriai - Y. Matsumura $\cdot$ Koum Sorith: Diagnosis of the stone of Banteay Kdei using the Resonance Method Cultumelle du Cambodia (Institute of Asian Cultures, Sophia University) No.14（1997）, pp. 233-236（英文)

13）盛合禧夫・松村吉康・赤間芳雄・ラオ キムリアン・クム ソリッド：カンボジア・アンコール遺跡における主要構築素 材に関する基礎的研究- 2 -, 東北工業大学紀要 I, 理工学 編，17号（1997），pp. 45-60

14）盛合禧夫・松村吉康・赤間芳雄・ラオ キムリアン・クム ソリッド：カンボジア・アンコール遺跡における主要構築素 材に関する基礎的研究- 3 -, 東北工業大学紀要 I, 理工学 編，18号，(1998), pp. 29-52

15）盛合禧夫・松村吉康・赤間芳雄・ラオ キムリアン・クム ソリッド：カンボジア・アンコール遺跡における主要構築素 材に関する基礎的研究 $-4-$, 東北工業大学紀要 I, 理工学 編, 19号, (1999), pp. 63-88

16）盛合禧夫・松村吉康・赤間芳雄・ラオキムリアン・クム ソリッド：カンボジア・アンコール遺跡における主要構築素 材に関する基礎的研究- 5 -, 東北工業大学紀要 I, 理工学 編，20号，(2000)，pp. 47-62

17）盛合禧夫・松村吉康：土・岩石およびコンクリートの診断方 法，東北地質調查業協会40年記念 (2000) pp. 37-56

18）土木学会：土木技術者のための岩盤力学（1975）pp. 129 （原稿受付2000年10月17日，原稿受理2001年 5 月28日） 